\title{
The clinical use of pretreatment NLR, PLR, and LMR in patients with esophageal squamous cell carcinoma: evidence from a meta-analysis
}

This article was published in the following Dove Press journal: Cancer Management and Research

Yugui Sun

Lifei Zhang

Department of Cardiothoracic Surgery, The Second Affiliated

Hospital of Guilin Medical University, Guilin, Guangxi Zhuang Autonomous

Region 54II99, China
Correspondence: Yugui Sun Department of Cardiothoracic Surgery, The Second Affiliated Hospital of Guilin Medical University, 212 Renming Road, Guilin, Guangxi Zhuang Autonomous Region 54I199, China

Email sunyugui2008@sina.com
Background and purpose: The relationship between neutrophil to lymphocyte ratio (NLR), platelet to lymphocyte ratio (PLR), and lymphocyte to monocyte ratio (LMR) and the prognostic and clinicopathological significance in patients with esophageal squamous cell carcinoma (ESCC) has been reported by many studies. However, inconsistent results have been presented. The current study aimed to investigate the prognostic and clinicopathological role of NLR, PLR, and LMR in patients with ESCC by meta-analysis.

Methods: Eligible studies were identified in databases and the relationship between NLR/PLR/ LMR and the prognosis or clinicopathological features in patients with ESCC was evaluated. OR or HR with $95 \%$ CI was calculated to estimate the risk or hazard association.

Result: Twenty-six studies including 8,586 ESCC patients were included for the analysis. We found that high NLR, PLR and low LMR were associated with poor overall survival/cancerspecific survival and event-free survival and malignant phenotypes such as deeper depth of invasion ( $\mathrm{T}$ ), positive lymph node metastasis $(\mathrm{N})$, and advanced TNM stage.

Conclusion: NLR, PLR, and LMR might serve as prognostic markers in patients with ESCC. Keywords: NLR, PLR, LMR, ESCC, prognosis

\section{Introduction}

Esophageal cancer (EC) ranks as the eighth most common cancer and is the sixth most common cause of death from cancer worldwide. ${ }^{1}$ Esophageal squamous cell carcinoma (ESCC), usually prevalent in Asia, accounts for about $90 \%$ of cases of EC. ${ }^{2,3}$ TNM staging is widely used as predictive models for prognosis in ESCC. ${ }^{4}$ However, the prognosis is usually very heterogeneous and unpredictable even in ESCC patients with same stage or similar pathologic features. It would be of great value to identify useful complementary biomarkers to stratify ESCC patients with high risk and to improve individualized treatment.

Recent evidence suggested that a systemic inflammatory response is associated with tumor development, apoptosis inhibition, angiogenesis promotion, and damage of DNA, thus resulting in tumor progression and metastasis. ${ }^{5}$ Various markers such as C-reactive protein (CRP) levels and blood neutrophil, lymphocyte, and platelet counts, either alone or expressed as ratios, might provide prognostic information on various cancers. Neutrophil to lymphocyte ratio (NLR), platelet to lymphocyte ratio (PLR), and lymphocyte to monocyte ratio (LMR) have recently been proposed as easily accessible inflammatory biomarkers. ${ }^{5,6}$ Although the prognostic role of NLR, PLR, and LMR and the prognosis of ESCC have been reported by many studies, inconsistent results have 
been presented. Previous meta-analyses have also investigated the prognostic role of NLR and PLR in EC. However, they also focused on one or two parameters (NLR and PLR). The prognostic role of LMR in ESCC has not been evaluated yet. What is more, after the publication of these meta-analyses, some new studies have been published. As a result, a metaanalysis is necessary to comprehensively evaluate the prognostic and clinicopathological significance of NLR, PLR, and LMR in patients with ESCC with updated evidence.

\section{Materials and methods}

\section{Literature search}

A comprehensive literature search was conducted in the databases of PubMed, EMBASE, and Web of Science up to March 31, 2018. The following terms were used to identify studies: "NLR" ("neutrophil to lymphocyte ratio," "neutrophil-to-lymphocyte ratio," "neutrophil-lymphocyte ratio," "neutrophil/lymphocyte ratio") OR "PLR" ("platelet lymphocyte ratio," "platelet-lymphocyte ratio," "platelet to lymphocyte ratio," "platelet-to-lymphocyte ratio," "platelet/ lymphocyte ratio") OR "LMR"("lymphocyte monocyte ratio," "lymphocyte-monocyte ratio," "lymphocyte to monocyte ratio," "lymphocyte-to-monocyte ratio," "lymphocyte/ monocyte ratio") AND "ESCC" ("esophageal neoplasm," "esophageal cancer," "esophageal carcinoma," "esophageal squamous cell carcinoma”).

\section{Inclusion and exclusion criteria}

The following inclusion criteria were applied to identify eligible studies that: 1) involved pathologically confirmed ESCC; 2) had full texts published in English or Chinese; 3) evaluated the relationship between pretreatment NLR/PLR/ LMR and survival outcomes or clinicopathological parameters, where survival outcomes included overall survival/ cancer-specific survival (OS/CSS) and event-free survival (EFS), including progression-free survival, disease-free survival, and recurrence-free survival; 4) provided sufficient information to estimate HR or OR and their 95\% CIs.

The exclusion criteria included the following: 1) cell line and animal studies, case reports, letters, reviews, or meta-analyses; 2) studies in which necessary data were not provided; 3) studies that reported HRs based on continuous NLR/PLR/LMR without a clear cutoff point; 4) overlapping studies and studies with low quality.

\section{Data extraction}

Two investigators (Sun and Zhang) independently reviewed the eligible studies and extracted the following data: surname of the first author, publication year, country, ethnicity, sample size, disease stage, histology type, cutoff value, and the outcomes. All data were then examined by the two investigators independently (Sun and Zhang). Disagreements were resolved by discussion.

\section{Quality assessment}

The quality of the methodology of the included studies was assessed by the Newcastle-Ottawa scale (NOS) recommended by the Cochrane Non-Randomized Studies Methods Working Group. ${ }^{7}$ Studies with five or more stars were defined as high quality studies. Quality assessment was performed by two investigators (Sun and Zhang) independently. Disagreements were resolved by discussion.

\section{Statistical analysis}

The relationship between NLR/PLR/LMR and OS/CSS or EFS was measured by the combined HRs and their $95 \%$ CIs extracted from each eligible study. The HR and its 95\% CI in each eligible study were directly extracted from the report, or indirectly estimated by methods described by Tierney et al. ${ }^{8}$ The combined HRs were estimated graphically by forest plots. ORs and their 95\% CIs were combined to estimate the relationship between NLR/PLR/LMR and clinicopathological parameters. The overall HR/OR and its 95\% CI overlap 1 were considered statistically significant and indicated a worse effect for the group with high NLR/PLR/LMR. Heterogeneity between studies was detected by the $\mathrm{Q}$ test and the $\mathrm{I}^{2}$ metric (no heterogeneity: $I^{2}=0 \%-25 \%$; moderate heterogeneity: 25\%-50\%; large heterogeneity: 50\%-75\%; and extreme heterogeneity: $75 \%-100 \%){ }^{9}$ If $P \geq 0.10$ in the $\mathrm{Q}$ test or $\mathrm{I}^{2}<50 \%$, the fixed effect model (Mantel-Haenszel method) was used. ${ }^{10}$ Otherwise, random effect model analysis was conducted. ${ }^{11}$ Subgroup analysis by different analytical methods (cutoff value, sample size, treatment, and geographic region) was performed in the analysis of OS/CSS or EFS. In addition, publication bias was assessed by the method reported by Begg and Egger. ${ }^{12,13}$ All $P$-values were two-tailed and a $P$-value $<0.05$ was considered statistically significant. Most of the statistical analyses in this study were conducted using the STATA software (version 11.2; StataCorp LP, College Station, TX, USA).

\section{Results \\ Literature search and study characteristics}

The initial search yielded 258 studies. After removing duplicate articles, 132 studies were left. On screening titles and 
abstracts, 77 studies were excluded because they obviously did not meet our selection criteria. The remaining 55 studies were further examined. After carefully reading the full articles, 29 studies were excluded: four meta-analysis studies, one letter, 12 studies that included adenocarcinoma or other subtypes of EC, two studies that did not provide outcomes of interest, two studies that did not provide the cutoff value of NLR/PLR/ LMR, and eight studies with overlapping data. Finally, 26 studies including 8,586 ESCC patients were available for further analysis $^{14-39}$ (Figure 1). Among these, 23 studies reported NLR, ${ }^{14,15,17-23,26-39} 12$ studies reported PLR, ${ }^{15,18-20,22,26,27,32-34,36,39}$ and LMR was reported by six studies. ${ }^{16,20,22,24-26}$ All the included studies were carried out in Asia (15 studies in China, 10 studies in Japan, and only one study in Korea). The sample size of 16 studies was $>200,{ }^{14,15,17,18,20,22,24-26,29-34,37}$ and the remaining 10 studies involved $<200$ patients. ${ }^{16,19,21,23,27,28,35,36,38,39}$ Thirteen studies reported both survival and clinicopathological data, ${ }^{15,16,20,22-26,31-34,37}$ and the other 13 studies only reported survival data. ${ }^{14,17-19,21,27-30,35,36,38,39}$ Most studies ${ }^{15,18-34,37}$ $(n=19)$ involved surgery-based treatment, six ${ }^{14,16,17,35,36,38}$ used chemoradiotherapy (CRT), and one study involved both treatments. ${ }^{39}$ The blood cell counts used to evaluate NLR/ PLR/LMR were obtained before treatment in all the included studies. The cutoff value of NLR in 23 studies ranged from 1.6 to $5 ; 13$ studies $^{14,15,17,19,21,27,30,31,33,35,36,38,39}$ had a cutoff value $\geq 3$, and the remaining 10 studies ${ }^{18,20,22,23,26,28,29,32,34,37}$ had a cutoff value $<3$. The cutoff value of PLR ranged from 103 to 244; five studies $15,19,26,33,39$ had a cutoff value $\geq 150$, and seven studies $^{18,20,22,23,27,34,36}$ had a cutoff value $<150$. Among the six studies that reported LMR, the cutoff value ranged from 2.57 to 4.02 . LMR $\geq 3.5$ was reported by three studies, ${ }^{16,20,22}$ and the remaining three studies ${ }^{24-26}$ reported LMR values $<3.5$. All included studies were scored high (with six stars or more). The baseline characteristics of the included studies are presented in Table 1. Details of blood testing time, treatment methods, and NOS score are presented in Table S1.
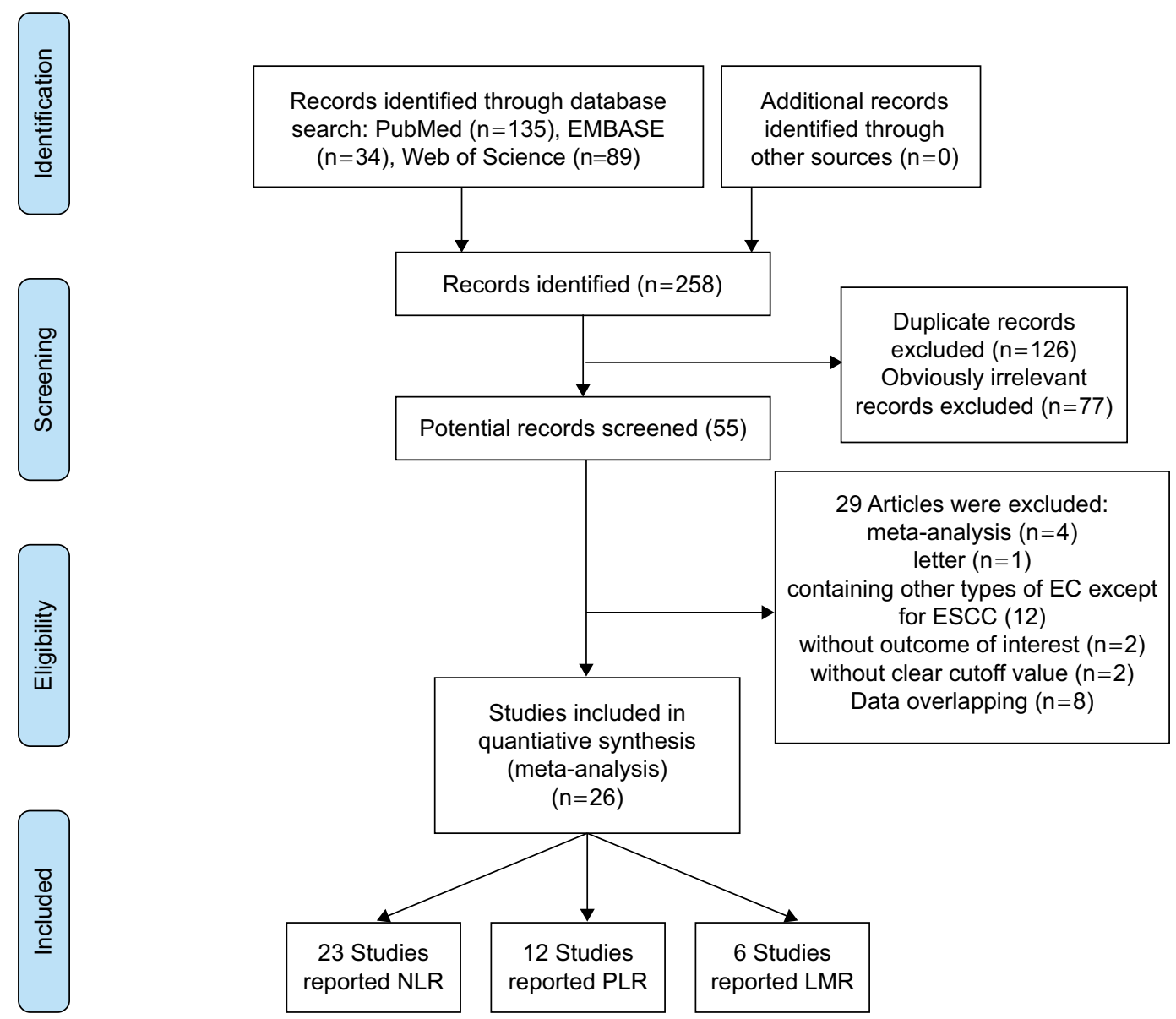

Figure I Flow diagram of studies selection procedure.

Abbreviations: NLR, neutrophil to lymphocyte ratio; PLR, platelet to lymphocyte ratio; LMR, lymphocyte to monocyte ratio; EC, esophageal cancer; ESCC, esophageal squamous cell carcinoma. 
Table I Main characteristics of all studies included in the meta-analysis

\begin{tabular}{|c|c|c|c|c|c|c|c|c|c|c|c|}
\hline Study & $\begin{array}{l}\text { Ethnicity } \\
\text { (country) }\end{array}$ & $\begin{array}{l}\text { Case } \\
\text { no }\end{array}$ & $\begin{array}{l}\text { Gender } \\
\text { (M/F) }\end{array}$ & Age & Stage & $\begin{array}{l}\text { NLR cutoff } \\
\text { (positive, \%) }\end{array}$ & $\begin{array}{l}\text { PLR cutoff } \\
\text { (positive, \%) }\end{array}$ & $\begin{array}{l}\text { LMR cutoff } \\
\text { (positive, \%) }\end{array}$ & $\begin{array}{l}\text { Follow-up } \\
\text { (months) }\end{array}$ & Outcome & $\begin{array}{l}\text { NOS } \\
\text { score }\end{array}$ \\
\hline $\begin{array}{l}\text { Yang et al } \\
(2018)^{34}\end{array}$ & $\begin{array}{l}\text { East-Asian } \\
\text { (China) }\end{array}$ & 515 & $418 / 97$ & 61 & I-III & $1.2(90.5)$ & $133(40.8)$ & NR & 35 & OS, C & 8 \\
\hline $\begin{array}{l}\text { Kunizaki et al } \\
(2018)^{39}\end{array}$ & $\begin{array}{l}\text { East-Asian } \\
\text { (Japan) }\end{array}$ & 116 & $98 / 18$ & 66 & 0-IV & $5(10.3)$ & $150(35.3)$ & NR & NR & OS & 6 \\
\hline $\begin{array}{l}\text { Sato et } \\
\text { al (CRT; } \\
2017)^{35}\end{array}$ & $\begin{array}{l}\text { East-Asian } \\
\text { (Japan) }\end{array}$ & 104 & NR & 65.3 & Advanced & $3(51.0)$ & NR & NR & NR & OS & 6 \\
\hline $\begin{array}{l}\text { Sato et al } \\
(\text { FP; 2017) }\end{array}$ & $\begin{array}{l}\text { East-Asian } \\
\text { (Japan) }\end{array}$ & 145 & NR & 63.6 & Advanced & $3(4 I .4)$ & NR & NR & NR & OS & 6 \\
\hline $\begin{array}{l}\text { Kijima et al } \\
(2017)^{38}\end{array}$ & $\begin{array}{l}\text { East-Asian } \\
\text { (Japan) }\end{array}$ & 98 & $86 / 12$ & 64.9 & III-IV & $3(38.8)$ & NR & NR & 15.4 & OS & 7 \\
\hline $\begin{array}{l}\text { Gao et al } \\
(2017)^{37}\end{array}$ & $\begin{array}{l}\text { East-Asian } \\
\text { (Japan) }\end{array}$ & $|, 28|$ & $988 / 293$ & NR & $0-I V$ & $2.86(4 \mid .3)$ & NR & NR & NR & OS & 7 \\
\hline $\begin{array}{l}\text { Miao et al } \\
(2017)^{36}\end{array}$ & $\begin{array}{l}\text { East-Asian } \\
\text { (Japan) }\end{array}$ & 168 & $134 / 34$ & 67.15 & II-IV & $3.34(35.7)$ & $103.75(59.5)$ & NR & 33 & OS & 7 \\
\hline $\begin{array}{l}\text { Zhou et al } \\
(2017)^{14}\end{array}$ & $\begin{array}{l}\text { East-Asian } \\
\text { (China) }\end{array}$ & 517 & $407 / 110$ & 65 & II-IV & $5(61)$ & NR & NR & 17 & OS, PFS & 8 \\
\hline $\begin{array}{l}\text { He et al } \\
(2017)^{15}\end{array}$ & $\begin{array}{l}\text { East-Asian } \\
\text { (China) }\end{array}$ & 317 & $268 / 49$ & 60 & I-IV & $3.3(49.5)$ & $150(30.9)$ & NR & 19.2 & $\begin{array}{l}\text { OS, } \\
\text { DFS, C }\end{array}$ & 8 \\
\hline $\begin{array}{l}\text { Liu et al } \\
(2017)^{16}\end{array}$ & $\begin{array}{l}\text { East-Asian } \\
\text { (China) }\end{array}$ & 162 & $127 / 35$ & 63 & II-III & NR & NR & $4.02(50)$ & 23.3 & OS, PFS, C & 7 \\
\hline $\begin{array}{l}\text { Zhang et al } \\
(2016)^{17}\end{array}$ & $\begin{array}{l}\text { East-Asian } \\
\text { (China) }\end{array}$ & 212 & $166 / 46$ & 60 & $T_{1-4} N_{0-1} M_{0-1}$ & $3(38.2)$ & NR & NR & 17 & OS, PFS & 6 \\
\hline $\begin{array}{l}\text { Zhang et al } \\
(2016)^{18}\end{array}$ & $\begin{array}{l}\text { East-Asian } \\
\text { (China) }\end{array}$ & 468 & $376 / 92$ & 59.5 & I-III & 2.5 & 117 & NR & 49.1 & OS, DFS & 6 \\
\hline $\begin{array}{l}\text { Toyokawa et } \\
\text { al }(20 \mid 6)^{19}\end{array}$ & $\begin{array}{l}\text { East-Asian } \\
\text { (Japan) }\end{array}$ & 185 & $152 / 33$ & 64 & I-IV & 3.61 (11.9) & $193(17.3)$ & NR & 81.5 & OS, RFS & 7 \\
\hline $\begin{array}{l}\text { Hirahara et al } \\
(2016)^{20}\end{array}$ & $\begin{array}{l}\text { East-Asian } \\
\text { (Japan) }\end{array}$ & 468 & $132 / 15$ & 66 & I-III & I.6 (74.8) & $147(46.2)$ & $4(56.5)$ & NR & CSS, C & 8 \\
\hline $\begin{array}{l}\text { Ikeguchi et al } \\
(2016)^{21}\end{array}$ & $\begin{array}{l}\text { East-Asian } \\
\text { (Japan) }\end{array}$ & 84 & $73 / 11$ & 65.7 & I-III & $3(3 I)$ & NR & NR & 35.5 & DFS & 6 \\
\hline $\begin{array}{l}\text { Geng et al } \\
(2016)^{22}\end{array}$ & $\begin{array}{l}\text { East-Asian } \\
\text { (China) }\end{array}$ & 916 & $696 / 220$ & 60 & I-III & I.7 (68.3) & $120(50)$ & 3.57 (54.1) & 39 & OS, C & 9 \\
\hline $\begin{array}{l}\text { Xiao et al } \\
(2016)^{23}\end{array}$ & $\begin{array}{l}\text { East-Asian } \\
\text { (China) }\end{array}$ & 121 & $106 / 15$ & 62 & I-III & I.77 (47.9) & NR & NR & 28 & OS, RFS, C & 9 \\
\hline $\begin{array}{l}\text { Zhu et al } \\
(2017)^{24}\end{array}$ & $\begin{array}{l}\text { East-Asian } \\
\text { (China) }\end{array}$ & 220 & $117 / 103$ & NR & T3NOMO & NR & NR & $3.36(42.7)$ & 53.25 & $\begin{array}{l}\text { OS, DFS, } \\
\text { C }\end{array}$ & 8 \\
\hline $\begin{array}{l}\text { Huang and } \\
\text { Feng }(2015)^{25}\end{array}$ & $\begin{array}{l}\text { East-Asian } \\
\text { (China) }\end{array}$ & 348 & $303 / 45$ & 59.2 & I-III & NR & NR & $2.93(58.3)$ & NR & CSS, C & 7 \\
\hline $\begin{array}{l}\text { Han et al } \\
(2015)^{26}\end{array}$ & $\begin{array}{l}\text { East-Asian } \\
\text { (China) }\end{array}$ & 218 & $|77 / 4|$ & 60.5 & I-III & $2.6(4 \mid .7)$ & $244(12.4)$ & $2.57(79.4)$ & NR & $\begin{array}{l}\text { OS, DFS, } \\
\text { C }\end{array}$ & 8 \\
\hline $\begin{array}{l}\text { ji et al } \\
(2016)^{27}\end{array}$ & $\begin{array}{l}\text { East-Asian } \\
\text { (China) }\end{array}$ & 41 & $38 / 3$ & 56.6 & I-III & $5(24.4)$ & $130(63.4)$ & NR & NR & OS & 7 \\
\hline $\begin{array}{l}\text { Jung et al } \\
(2016)^{28}\end{array}$ & $\begin{array}{l}\text { East-Asian } \\
\text { (Korea) }\end{array}$ & 119 & $112 / 7$ & 63.6 & I-III & $2.97(19.3)$ & NR & NR & 28.68 & OS, DFS & 6 \\
\hline $\begin{array}{l}\text { Kosumi et al } \\
(2016)^{29}\end{array}$ & $\begin{array}{l}\text { East-Asian } \\
\text { (Japan) }\end{array}$ & 283 & $248 / 35$ & NR & I-IV & $1.94(49.8)$ & NR & NR & 33.6 & OS & 6 \\
\hline $\begin{array}{l}\text { Arigami et al } \\
(2015)^{30}\end{array}$ & $\begin{array}{l}\text { East-Asian } \\
\text { (Japan) }\end{array}$ & 309 & $210 / 28$ & 65 & I-III & $3(17.6)$ & NR & NR & 26 & OS & 7 \\
\hline $\begin{array}{l}\text { Duan et al } \\
(20 \mid 5)^{31}\end{array}$ & $\begin{array}{l}\text { East-Asian } \\
\text { (China) }\end{array}$ & 371 & $276 / 95$ & 57 & Ib-IIIc & $3(19.9)$ & NR & NR & 66 & $\begin{array}{l}\text { CSS, RFS, } \\
\text { C }\end{array}$ & 8 \\
\hline $\begin{array}{l}\text { Xie et al } \\
(2016)^{32}\end{array}$ & $\begin{array}{l}\text { East-Asian } \\
\text { (China) }\end{array}$ & 317 & $244 / 73$ & 58.1 & I-III & 2.1 (46.7) & $103(62.1)$ & NR & 46 & CSS, C & 6 \\
\hline $\begin{array}{l}\text { Feng et al } \\
(20 \mid 4)^{33}\end{array}$ & $\begin{array}{l}\text { East-Asian } \\
\text { (China) }\end{array}$ & 483 & $411 / 72$ & 59.1 & I-III & $3.5(36.8)$ & $150(45.5)$ & NR & NR & OS, C & 8 \\
\hline
\end{tabular}

Abbreviations: NOS, Newcastle-Ottawa scale; NR, not reported; C, clinicopathological parameters; CRT, chemoradiotherapy; CSS, cancer-specific survival; F, female; FP, 5-fluorouracil and cisplatin; M, male; OS, overall survival; NLR, neutrophil to lymphocyte ratio; PLR, platelet to lymphocyte ratio; LMR, lymphocyte to monocyte ratio; PFS, progression-free survival; DFS, disease-free survival; RFS, recurrence-free survival; NR, no report. 


\section{The prognostic role of NLR in ESCC}

Twenty-two studies reported the relationship between NLR and OS/CSS in ESCC. . $14,15,17-20,22,23,26-39$ The overall analysis suggested that high NLR was associated with worse OS/ CSS $\left(\mathrm{HR}=1.54,95 \% \mathrm{CI}=1.39-1.74, P<0.001, \mathrm{I}^{2}=53.9 \%\right.$, $P=0.001)$. Eleven studies reported the relationship between NLR and EFS in ESCC. ${ }^{14,15,17-19,21,23,24,26,28,31}$ Similarly, high NLR was associated with worse EFS (HR $=1.34$, 95\%
$\left.\mathrm{CI}=1.22-1.46, P<0.001, \mathrm{I}^{2}=20 \%, P=0.25\right)($ Table 2 and Figure 2).

The following clinicopathological parameters extracted from studies were collected for analysis: sex, ${ }^{15,18,20,22,23,26,27,31-}$ 34,37 tumor location, ${ }^{15,18,20,22,23,26,27,31-34,37}$ differentiation, ${ }^{15,18,22,26,27,31-34,37}$ depth of invasion (T), ${ }^{18,20,22,23,26,27,31-34}$ tumor length, ${ }^{15,26,33}$ lymph node metastasis, ${ }^{15,18,20,22,23,26,27,31-34}$ and TNM stage. ${ }^{15,20,22,23,26,27,31,32,34,37} \mathrm{We}$ found high NLR was

A

\begin{tabular}{|c|c|c|c|}
\hline \multicolumn{2}{|l|}{$\begin{array}{l}\text { Study } \\
\text { ID }\end{array}$} & \multirow{2}{*}{$\frac{\mathrm{HR}(95 \% \mathrm{Cl})}{1.59(1.13,2.23)}$} & \multirow{2}{*}{$\begin{array}{l}\% \\
\text { Weight } \\
5.08\end{array}$} \\
\hline Duan H, 2015 & $\longrightarrow$ & & \\
\hline Feng J, 2014 & $\rightarrow-1$ & $1.34(1.01,1.77)$ & 6.05 \\
\hline Han L, 2015 & & $1.13(0.76,1.68)$ & 4.34 \\
\hline Ji W, 2015 & & $3.50(1.18,10.40)$ & 0.94 \\
\hline Jung J, 2015 & & $1.23(1.05,1.44)$ & 8.09 \\
\hline Kosumi K, 2015 & & $1.84(1.17,2.93)$ & 3.65 \\
\hline Geng Y, 2016 & & $1.18(0.97,1.44)$ & 7.43 \\
\hline Xie X, 2014 & $\multimap$ & $1.20(0.83,1.72)$ & 4.78 \\
\hline Zhang F, 2016 & $\rightarrow$ & $1.28(0.93,1.76)$ & 5.41 \\
\hline Toyokawa T, 2016 & & $1.19(0.63,2.27)$ & 2.28 \\
\hline Hirahara N, 2016 & & $1.47(0.75,2.73)$ & 2.28 \\
\hline Xiao Q, 2016 & & $2.03(1.26,3.26)$ & 3.50 \\
\hline Zhou X, 2017 & & $1.86(1.50,2.30)$ & 7.13 \\
\hline Arigami T, 2015 & & $1.94(1.04,3.53)$ & 2.47 \\
\hline Zhang P, 2016 & & $1.19(0.86,1.65)$ & 5.30 \\
\hline $\mathrm{He} Y, 2017$ & & $1.37(1.01,1.84)$ & 5.72 \\
\hline Yang Y, 2018 & & $1.48(0.90,2.41)$ & 3.34 \\
\hline Miao C, 2017 & & $2.37(1.32,4.25)$ & 2.63 \\
\hline Sato Y, 2017 & & $2.24(1.43,3.49)$ & 3.79 \\
\hline Sato Y, 2017 & & $2.19(1.46,3.27)$ & 4.26 \\
\hline Kijima T, 2017 & $\frac{1}{1} \rightarrow$ & $2.07(1.10,3.92)$ & 2.33 \\
\hline Gao G, 2017 & 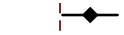 & $1.89(1.57,2.28)$ & 7.59 \\
\hline Kunizaki M, 2018 & & $3.18(1.43,7.07)$ & 1.62 \\
\hline Overall $\left(I^{2}=53.9 \%, P=0.001\right)$ & 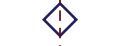 & $1.55(1.39,1.74)$ & 100.00 \\
\hline \multicolumn{4}{|l|}{ Note: Weights are from random effects analysi\$ } \\
\hline $\begin{array}{lll}1 & 1 \\
0.0962 & 1\end{array}$ & 1 & & \\
\hline
\end{tabular}

B

NLR and EFS

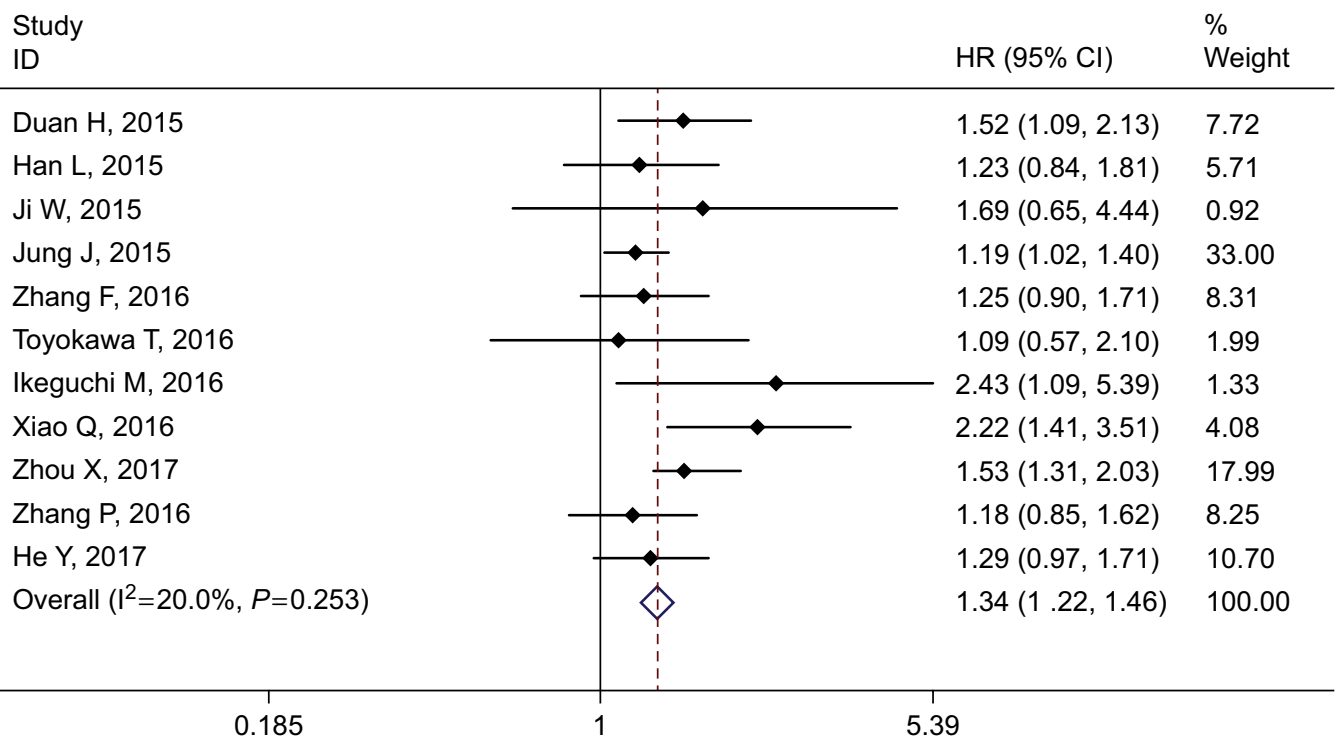

Figure 2 Forest plot of HR for the association of NLR with OS/CSS (A) and EFS (B) in patients with ESCC.

Abbreviations: OS, overall survival; CSS, cancer-specific survival; EFS, event-free survival; ESCC, esophageal squamous cell carcinoma; NLR, neutrophil to lymphocyte ratio. 
Table 2 Meta-analysis results of NLR, PLR, and LMR and OS/CSS and EFS in patients with ESCC

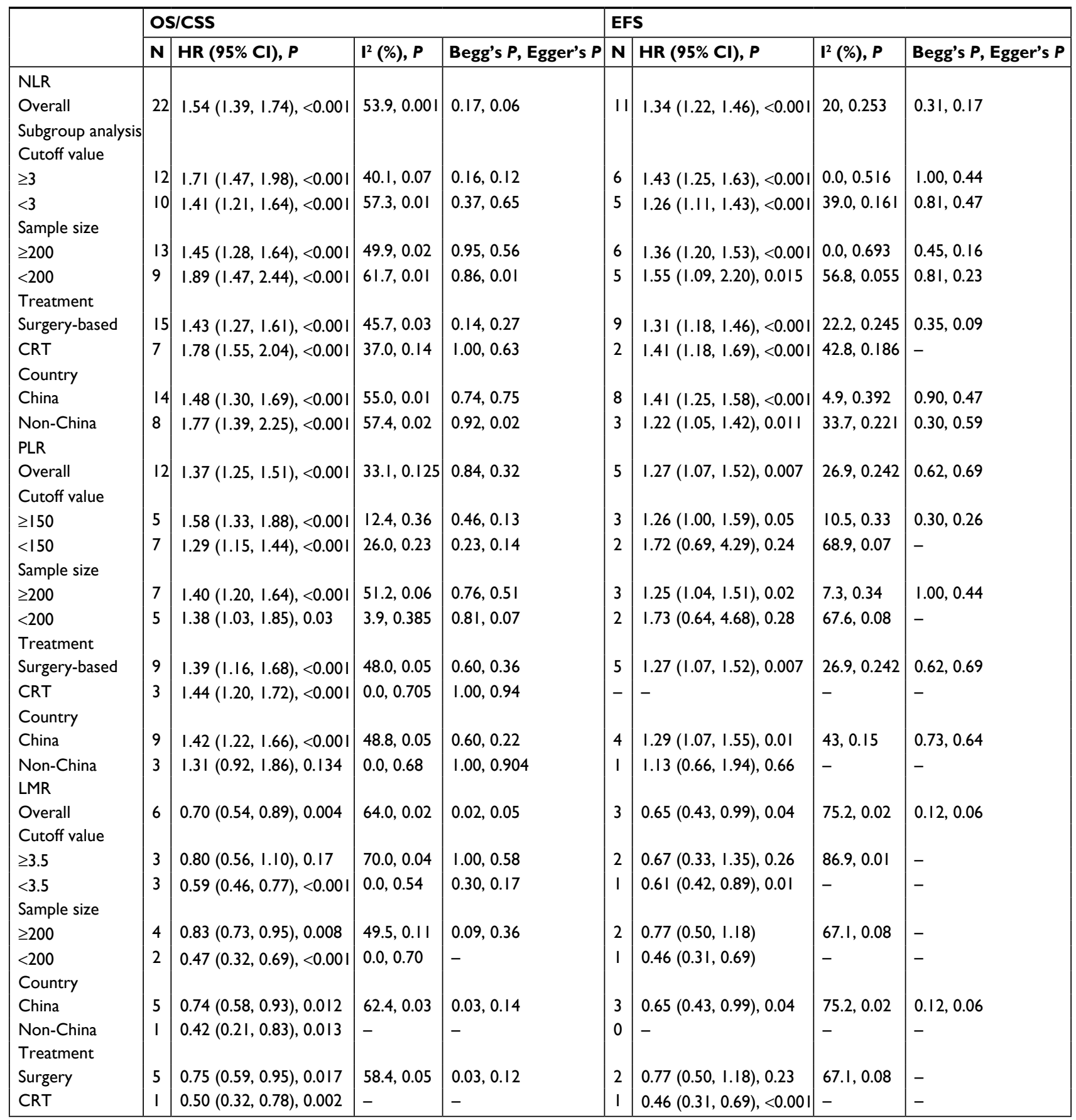

Abbreviations: CRT, chemoradiotherapy; CSS, cancer-specific survival; EFS, event-free survival; OS, overall survival; NLR, neutrophil to lymphocyte ratio; PLR, platelet to lymphocyte ratio; LMR, lymphocyte to monocyte ratio; ESCC, esophageal squamous cell carcinoma.

more common in males than in females (male vs female: OR $=1.58,95 \% \mathrm{CI}=1.19-2.10, P=0.002)$; high NLR was associated with deeper depth of invasion (T3-T4 vs T1-T2: OR $=1.95,95 \% \mathrm{CI}=1.46-2.60, P<0.001)$, longer tumor length ( $\geq 3$ vs $<3$ cm: $\mathrm{OR}=2.82,95 \% \mathrm{CI}=1.67-4.77, P<0.001$ ), positive lymph node metastasis (yes vs no: $\mathrm{OR}=1.27,95 \% \mathrm{CI}$ $=1.03-1.57, P=0.026$ ), and advanced stage (III-IV vs I-II: OR $=1.47,95 \% \mathrm{CI}=1.28-1.69, P<0.001)$. No significant association was found in tumor location and differentiation (Table 3 ).

\section{The prognostic role of PLR in ESCC}

The relationship between PLR and OS/CSS was investigated by 12 studies. ${ }^{15,18-20,22,26,27,32-34,36,39}$ We found that ESCC patients with high PLR may have worse OS/CSS (HR $=1.37,95 \% \mathrm{CI}=1.25-1.51, P<0.001, \mathrm{I}^{2}=33.1 \%, P=0.125$ ). The pooled analysis of five studies ${ }^{15,18,19,26,31}$ also suggested high PLR was associated with worse EFS (HR $=1.27,95 \%$ $\mathrm{CI}=1.07-1.52, P=0.007, \mathrm{I}^{2}=26.9 \%, P=0.242$ ) (Table 2 and Figure 3). 
Table 3 Meta-analysis results of NLR, PLR, and LMR and clinicopathological parameters in patients with ESCC

\begin{tabular}{|c|c|c|c|c|c|c|c|c|c|c|c|c|}
\hline & \multicolumn{2}{|r|}{ NLR } & \multirow[b]{2}{*}{$I^{2}(\%), P$} & \multirow[b]{2}{*}{$\begin{array}{l}\text { Begg } \\
P\end{array}$} & \multicolumn{2}{|r|}{ PLR } & \multirow[b]{2}{*}{$I^{2}(\%), P$} & \multirow[b]{2}{*}{$\begin{array}{l}\text { Begg } \\
P\end{array}$} & \multicolumn{2}{|r|}{ LMR } & \multirow[b]{2}{*}{$I^{2}(\%), P$} & \multirow[b]{2}{*}{$\begin{array}{l}\text { Begg } \\
P\end{array}$} \\
\hline & $\mathbf{N}$ & OR (95\% Cl), $P$ & & & $\mathbf{N}$ & $\begin{array}{l}\text { OR }(95 \% \\
\mathrm{Cl}), P\end{array}$ & & & $\mathbf{N}$ & $\begin{array}{l}\text { OR ( } 95 \% \\
\mathrm{Cl}), P\end{array}$ & & \\
\hline Sex (M vs F) & 12 & $\begin{array}{l}1.58(1.19,2.10) \\
0.002\end{array}$ & $62.1,0.002$ & 0.63 & 7 & $\begin{array}{l}0.84(0.50 \\
1.44), 0.53\end{array}$ & $\begin{array}{l}75.5 \\
<0.00 \text { I }\end{array}$ & 0.29 & 7 & $\begin{array}{l}0.61(0.37 \\
1.00), 0.049\end{array}$ & $\begin{array}{l}75.1 \\
0.001\end{array}$ & 0.65 \\
\hline Location (U/M vs L) & 11 & $\begin{array}{l}1.01(0.81,1.26) \\
0.92\end{array}$ & $50.2,0.02$ & 0.63 & 7 & $\begin{array}{l}1.00(0.84 \\
1.20), 0.97\end{array}$ & $17.8,0.29$ & 0.88 & 7 & $\begin{array}{l}1.23(1.03 \\
1.46), 0.021\end{array}$ & $0.0,0.71$ & 0.65 \\
\hline $\begin{array}{l}\text { Tumor differentiation } \\
\text { (poor vs moderate/high) }\end{array}$ & 10 & $\begin{array}{l}0.99(0.76,1.29), \\
0.66\end{array}$ & $63.9,0.003$ & 0.86 & 7 & $\begin{array}{l}1.35(1.03 \\
1.78), 0.03\end{array}$ & $44.3,0.10$ & 1.00 & 5 & $\begin{array}{l}0.87(0.60 \\
1.25), 0.44\end{array}$ & $\begin{array}{l}58.9 \\
0.045\end{array}$ & 0.33 \\
\hline $\begin{array}{l}\text { Depth of invasion } \\
\text { (T3-T4 vs TI-T2) }\end{array}$ & 10 & $\begin{array}{l}1.95(1.46,2.60) \\
<0.001\end{array}$ & $60.0,0.007$ & 0.86 & 6 & $\begin{array}{l}1.49(1.26 \\
1.76),<0.001\end{array}$ & $0.0,0.82$ & 0.13 & 5 & $\begin{array}{l}0.58(0.48 \\
0.69),<0.001\end{array}$ & $\begin{array}{l}36.7 \\
0.18\end{array}$ & 0.33 \\
\hline $\begin{array}{l}\text { Tumor length } \\
(\geq 3 \mathrm{vs}<3 \mathrm{~cm})\end{array}$ & 3 & $\begin{array}{l}2.82(1.67,4.77), \\
<0.001\end{array}$ & $63.1,0.066$ & 0.6 & 3 & $\begin{array}{l}1.82(1.32 \\
2.49),<0.001\end{array}$ & $41.3,0.18$ & 0.60 & 3 & $\begin{array}{l}0.86(0.63 \\
1.18), 0.35\end{array}$ & $\begin{array}{l}59.7 \\
0.08\end{array}$ & 0.6 \\
\hline $\begin{array}{l}\text { Lymph node metastasis } \\
\text { (yes vs no) }\end{array}$ & 11 & $\begin{array}{l}1.27(1.03,1.57), \\
0.026\end{array}$ & $46.4,0.045$ & 0.21 & 8 & $\begin{array}{l}1.53(1.20 \\
1.96), 0.001\end{array}$ & $52.2,0.04$ & 1.00 & 6 & $\begin{array}{l}0.68(0.57 \\
0.82),<0.001\end{array}$ & $0.0,0.60$ & 0.85 \\
\hline Stage (III-IV vs I-II) & 10 & $\begin{array}{l}1.47(1.28,1.69) \\
<0.001\end{array}$ & $0.0,0.64$ & 1.00 & 6 & $\begin{array}{l}1.32(1.12 \\
1.57), 0.001\end{array}$ & II.I, 0.34 & 0.02 & 4 & $\begin{array}{l}0.63(0.50 \\
0.80),<0.001\end{array}$ & $0.0,0.48$ & 0.09 \\
\hline
\end{tabular}

Abbreviations: NLR, neutrophil to lymphocyte ratio; PLR, platelet to lymphocyte ratio; LMR, lymphocyte to monocyte ratio; ESCC, esophageal squamous cell carcinoma; $\mathrm{M}$, male; F, female; U/M, upper/middle; L, lower.

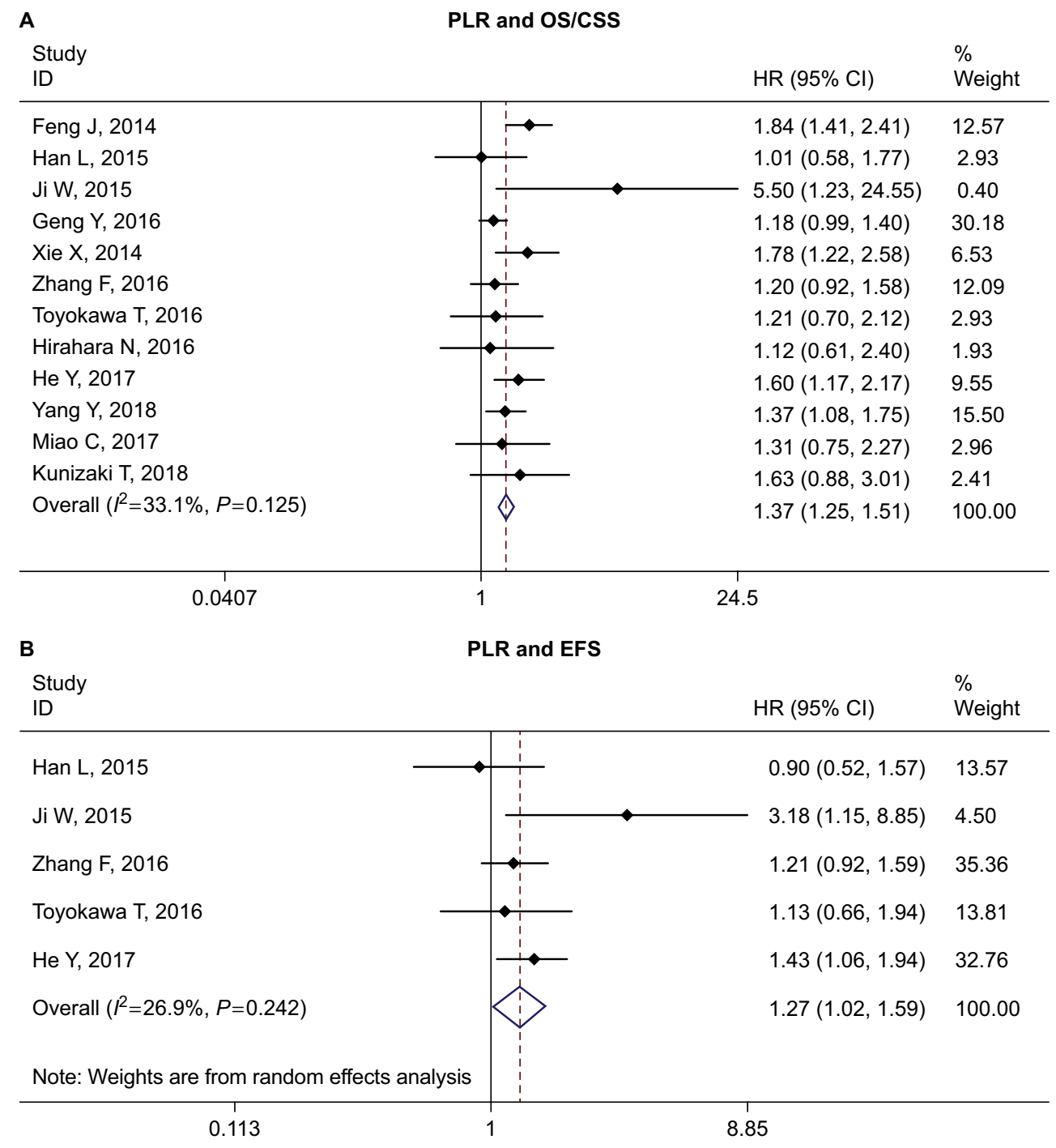

Figure 3 Forest plot of HR for the association of PLR with OS/CSS (A) and EFS (B) in patients with ESCC.

Abbreviations: OS, overall survival; CSS, cancer-specific survival; EFS, event-free survival; ESCC, esophageal squamous cell carcinoma; PLR, platelet to lymphocyte ratio. 
Eight studies ${ }^{15,18,20,22,26,32-34}$ reported the relationship between PLR and clinicopathological parameters. We also found that high PLR was associated with depth of invasion (T3-T4 vs T1-T2: OR $=1.49,95 \% \mathrm{CI}=1.26-1.76, P>0.001$ ), tumor length ( $\geq 3 \mathrm{vs}<3 \mathrm{~cm}$ : OR $=1.82,95 \% \mathrm{CI}=1.32-2.49$, $P<0.001$ ), lymph node metastasis (yes vs no: $\mathrm{OR}=1.53$, $95 \% \mathrm{CI}=1.20-1.96, P=0.001$ ), and stage (III-IV vs I-II: OR $=1.32,95 \% \mathrm{CI}=1.12-1.57, P=0.001)$. No association was found in sex, tumor location, and differentiation (Table 3).

\section{The prognostic role of LMR in ESCC}

The impact of LMR on OS/CSS was evaluated by six studies, ${ }^{16,20,22,24-26}$ and three studies ${ }^{16,24,26}$ evaluated the relationship between LMR and EFS. The combined HR for OS/CSS and EFS suggested that high LMR might be associated with better survival $(\mathrm{HR}=0.70,95 \% \mathrm{CI}=0.54-0.89, P<0.001$ for $\mathrm{OS} / \mathrm{CSS} ; \mathrm{HR}=0.65,95 \% \mathrm{CI}=0.43-0.99, P<0.001$ for EFS, respectively.) (Table 2 and Figure 4).

The relationship between LMR and clinicopathological parameters was evaluated by six studies. ${ }^{16,20,22,24-26}$ Low LMR was associated with sex (male vs female: $\mathrm{OR}=0.61,95 \%$ $\mathrm{CI}=0.37-1.00, P=0.049$ ), tumor location (upper/middle vs lower: $\mathrm{OR}=1.23,95 \% \mathrm{CI}=1.03-1.46, P=0.021$ ), depth of invasion (T3-T4 vs T1-T2: OR $=0.58,95 \% \mathrm{CI}=0.48-0.69$, $P<0.001$ ), lymph node metastasis (yes vs no: $\mathrm{OR}=0.68$, $95 \% \mathrm{CI}=0.57-0.82, P<0.001$ ), and stage (III-IV vs I-II: OR $=0.63,95 \% \mathrm{CI}=0.50-0.80, P<0.001)$. No association was found in tumor differentiation and tumor length (Table 3 ).

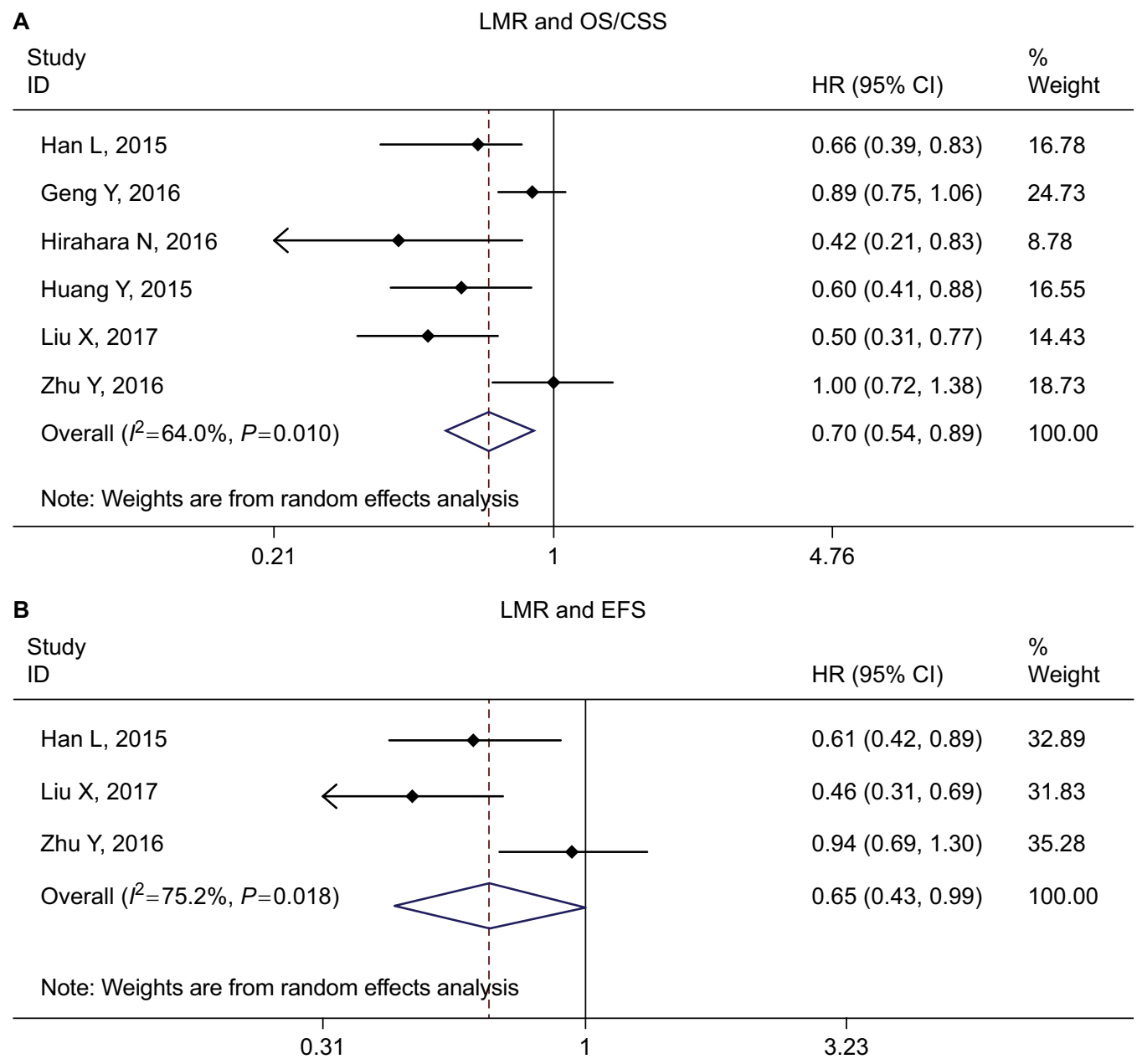

Figure 4 Forest plot of HR for the association of LMR with OS/CSS (A) and EFS (B) in patients with ESCC.

Abbreviations: OS, overall survival; CSS, cancer-specific survival; EFS, event-free survival; ESCC, esophageal squamous cell carcinoma; LMR, lymphocyte to monocyte ratio. 


\section{Subgroup analysis}

Subgroup analysis was further conducted according to cutoff value ( $\geq 3$ vs $<3$ for NLR, $\geq 150$ vs $<150$ for PLR, and $\geq 3.5$ vs $<3.5$ for LMR), sample size ( $\geq 200$ vs $<200$ ), treatment (surgery-based vs CRT only), and geographic region (China vs non-China). The results of the subgroup analyses are presented in Table 2.

When the subgroup analysis was performed according to cutoff value, the HRs in studies with cutoff value $\geq 3$ were 1.71 and 1.43 for OS/CSS and EFS, respectively, which were more significant than studies with cutoff value $<3$ (HRs were 1.41 and 1.26 for OS/CSS and EFS, respectively). This suggested that the higher the NLR, the worse the prognosis of the patient. Also, the heterogeneity in studies with cutoff value $\geq 3\left(\mathrm{I}^{2}=40.1 \%\right.$ and $0.0 \%$ for OS/CSS and EFS, respectively) was lower than studies with cutoff value $<3\left(\mathrm{I}^{2}=57.3 \%\right.$ and $39.0 \%$ for OS/CSS and EFS, respectively). When the subgroup analysis was performed according to treatment (surgery-based vs CRT only) in OS/CSS, $\mathrm{I}^{2}$ decreased in both subgroups $\left(\mathrm{I}^{2}=45.7 \%\right.$ and $37.0 \%$ for surgery-based and CRT only studies, respectively). Treatment methods might be the source of heterogeneity. Other subgroup analyses suggested a significant association between high NLR and poor OS/ CSS and EFS.

In studies exploring the prognostic role of PLR in ESCC, $\mathrm{I}^{2}$ in the overall analysis was $33.1 \%(P=0.125)$ for OS/CSS. When the subgroup analysis was performed according to cutoff value, both studies with cutoff value $\geq 150$ and $<150$ showed significant association. However, the heterogeneity in each group was reduced when compared with the overall analysis $\left(\mathrm{I}^{2}=12.4 \%, P=0.36\right.$ for cutoff value $\geq 150 ; \mathrm{I}^{2}=26.0 \%$, $P=0.23$ for cutoff value $<150$ ). This may suggest that different cutoff values of PLR maybe one of the sources of heterogeneity.

Low LMR was associated with poor OS/CSS in all subgroup analyses. The heterogeneity in studies with sample size $\geq 200$ was moderate $\left(\mathrm{I}^{2}=49.5 \%, P=0.114\right)$, and no heterogeneity was observed in studies with sample size $<200\left(\mathrm{I}^{2}=0.0 \%, P=0.70\right)$. As a result, the high heterogeneity $\left(\mathrm{I}^{2}=64.0 \%, P=0.016\right)$ in the overall analysis might account for the subgroup analysis by sample size $(\geq 200$ and $<200)$.

\section{Publication bias}

Begg's and Egger's tests were applied for publication bias detection. Only the analysis of the effect of LMR on OS/ CSS showed significant publication bias $\left(P_{\text {Begg }}=0.02, P_{\text {Egger }}\right.$ $=0.05$ ); other comparisons did not show any publication bias (Table 2).

\section{Discussion}

It is now generally recognized that inflammation response plays a critical role in tumor progression and may influence survival outcomes in patients with cancer. As systematic inflammatory markers, high neutrophil, platelet, and macrophage counts, low lymphocyte, and also high NLR, PLR, and low LMR have been recognized to be associated with unfavorable prognosis in solid tumors. In this meta-analysis, we comprehensively assessed the prognostic role of NLR, PLR, and LMR in ESCC by collecting the data set of 26 studies including 8,586 ESCC patients. We found that high NLR, PLR and low LMR were associated with poor survival and malignant phenotype such as deeper depth of invasion (T), positive lymph node metastasis $(\mathrm{N})$, and advanced TNM stage. This preclinical and clinical research may lay the foundation for NLR, PLR, and LMR to serve as useful prognostic biomarkers and to stratify ESCC patients with high risk.

Previous meta-analyses have investigated the prognostic role of NLR and PLR in EC. Yang et $\mathrm{al}^{40}$ first investigated the relationship between NLR and EC by summarizing six studies involving 1,633 patients with EC. Yodying et al analyzed seven studies including 1,540 EC patients to investigate the prognostic role of NLR and PLR in EC. ${ }^{41}$ Huang et $\mathrm{al}^{42}$ focused on the relationship between NLR and ESCC. Nine studies with 2,513 patients were included in their study. In a study by Zhao et al, ${ }^{43} 16$ studies including 6,699 patients were utilized to investigate the prognostic role of PLR in EC patients. All these meta-analyses found that high NLR and PLR were associated with poor survival in EC. Our study showed the following advancements when compared with previous work. Firstly, our study was more comprehensive than earlier work. Prior to this, the prognostic role of NLR was mostly investigated by meta-analyses. One study evaluated both NLR and PLR; ${ }^{41}$ PLR was investigated by one study. ${ }^{43}$ The prognostic role of LMR had not been investigated yet. As NLR, PLR, and LMR were the mostly studied inflammatory biomarkers, for the first time we comprehensively investigated the prognostic role of the three inflammatory markers (NLR, PLR, and LMR) in ESCC. We found all these three markers to be associated with tumor progression and prognosis of ESCC patients. Secondly, the sample size in our analysis was larger than any previous metaanalysis. Twenty-six studies including 8,586 ESCC patients were available in our study, which was larger than the study by Yang et $\mathrm{al}^{40}(1,633)$, Yodying et $\mathrm{al}^{41}(1,540)$, Huang et $\mathrm{al}^{42}$ $(2,513)$, and Zhao et al ${ }^{43}(6,699)$. To some degree, our result was more robust and reliable than previous work. Lastly, as 
ESCC was a major type of EC (accounted for 90\% of EC cases), we only focused on the prognostic role of NLR, PLR, and LMR on ESCC. This would reduce the potential bias induced by histology type. In a nutshell, our meta-analysis is more updated and comprehensive than previous works.

As ESCC is a complicated disease, many clinical variables or biomarkers are associated with the prognosis of ESCC, for example hemoglobin, CRP, squamous cell carcinoma antigen (SCC-Ag), fibrinogen, nutritional parameters, cell-free circulating tumor DNA, and circulating noncoding RNA. NLR, PLR, and LMR were just systemic inflammatory responserelated markers that affected the prognosis of ESCC. In some cases, these factors may even contradict each other. For example, all NLR, PLR and LMR are high, how to determine the prognosis of ESCC? As no studies have reported such a case, and available data are insufficient to analyze this situation, we failed to explore the result. However, to predict the prognosis of ESCC more accurately and usefully, we think it is better to combine these useful biomarkers together just as the Glasgow prognostic score, an inflammation-based score which combined albumin and C-reactive protein (CRP).

Some limitations should also be acknowledged.

Firstly, the cutoff value of NLR/PLR/LMR varied in the included studies. The criteria and method used in different institutions to determine the cutoff value were different; we could not propose an appropriate cutoff value by statistical analysis. This may affect the results and induce unavoidable potential heterogeneity and bias. It may limit the usefulness of NLR/PLR/ LMR in clinical practice. Therefore, a standard and uniform cutoff value defining NLR/PLR/LMR is needed. Secondly, some factors such as age, sex, smoking history, tumor stage, comorbidities, and treatment method may affect the level of NLR/PLR/LMR, ${ }^{44,45}$ and also the prognosis in ESCC. However, we could not conduct a stratified analysis to assess the effects of confounding factors on the prognostic role of NLR/PLR/LMR in ESCC patients because of the limited information provided in the original studies. Lastly, publication bias was detected in the comparison of LMR in OS. Apart from this, potential publication biases may exist. Studies that failed to get published because of negative or null results could not be identified in our literature search and thus were not included in this analysis. In addition, some reports that did not provide sufficient data were also excluded from our analyses of the publications.

In conclusion, our analysis suggested high NLR, PLR and low LMR were associated with poor survival and malignant phenotype in ESCC patients. With the limitations, heterogeneities, and bias of meta-analysis, our conclusions in this study need to be interpreted with caution. Future large prospective studies with rigorously designed methodologies are warranted to confirm our results.

\section{Disclosure}

The authors report no conflicts of interest in this work.

\section{References}

1. Torre LA, Bray F, Siegel RL, Ferlay J, Lortet-Tieulent J, Jemal A. Global cancer statistics, 2012. CA: A Cancer Journal for Clinicians. 2015;65(2):87-108.

2. Pennathur A, Gibson MK, Jobe BA, Luketich JD. Oesophageal carcinoma. Lancet. 2013;381(9864):400-412.

3. Lin Y, Totsuka Y, He Y, et al. Epidemiology of esophageal cancer in Japan and China. J Epidemiol. 2013;23(4):233-242.

4. Rice TW, Blackstone EH. Esophageal cancer staging: past, present, and future. Thorac Surg Clin. 2013;23(4):461-469.

5. Munn LL. Cancer and inflammation. Wiley Interdiscip Rev Syst Biol Med. 2017;9(2):e1370.

6. Guthrie GJ, Charles KA, Roxburgh CS, Horgan PG, Mcmillan DC, Clarke SJ. The systemic inflammation-based neutrophil-lymphocyte ratio: experience in patients with cancer. Crit Rev Oncol Hematol. 2013;88(1):218-230.

7. Wells GA, Shea B, O'Connell D, et al. The Newcastle-Ottawa Scale (NOS) for assessing the quality of nonrandomised studies in metaanalyses; 2014. Available from: www.ohri.ca/programs/clinical_epidemiology/oxford.asp. Accessed April 25, 2017.

8. Tierney JF, Stewart LA, Ghersi D, Burdett S, Sydes MR. Practical methods for incorporating summary time-to-event data into meta-analysis. Trials. 2007;8:16.

9. Higgins JP, Thompson SG, Deeks JJ, Altman DG. Measuring inconsistency in meta-analyses. BMJ. 2003;327(7414):557-560.

10. Mantel N, Haenszel W. Statistical aspects of the analysis of data from retrospective studies of disease. J Natl Cancer Inst. 1959;22(4):719-748.

11. Dersimonian R, Laird N. Meta-analysis in clinical trials. Control Clin Trials. 1986;7(3):177-188.

12. Begg CB, Mazumdar M. Operating characteristics of a rank correlation test for publication bias. Biometrics. 1994;50(4):1088-1101.

13. Egger M, Davey Smith G, Schneider M, Minder C. Bias in meta-analysis detected by a simple, graphical test. BMJ. 1997;315(7109):629-634.

14. Zhou XL, Li YQ, Zhu WG, et al. Neutrophil-to-lymphocyte ratio as a prognostic biomarker for patients with locally advanced esophageal squamous cell carcinoma treated with definitive chemoradiotherapy. Sci Rep. 2017;7:42581.

15. He YF, Luo HQ, Wang W. Preoperative NLR and PLR in the middle or lower ESCC patients with radical operation. Eur J Cancer Care. 2017;26(2)

16. Liu X, Li M, Zhao F, et al. The lymphocyte-monocyte ratio predicts tumor response and survival in patients with locally advanced esophageal cancer who received definitive chemoradiotherapy. Onco Targets Ther. 2017;10:871-877.

17. Zhang P, Xi M, Zhao L, et al. Comparison of two inflammation-based prognostic scores in patients with thoracic esophageal cancer undergoing chemoradiotherapy. Int J Clin Exp Med. 2016;9(2):1764-1771.

18. Zhang F, Chen Z, Wang P, Hu X, Gao Y, He J. Combination of platelet count and mean platelet volume (COP-MPV) predicts postoperative prognosis in both resectable early and advanced stage esophageal squamous cell cancer patients. Tumour Biol. 2016;37(7):9323-9331.

19. Toyokawa T, Kubo N, Tamura T, et al. The pretreatment Controlling Nutritional Status (CONUT) score is an independent prognostic factor in patients with resectable thoracic esophageal squamous cell carcinoma: results from a retrospective study. BMC Cancer. 2016;16:722.

20. Hirahara N, Matsubara T, Mizota Y, Ishibashi S, Tajima Y. Prognostic value of preoperative inflammatory response biomarkers in patients with esophageal cancer who undergo a curative thoracoscopic esophagectomy. BMC Surg. 2016;16(1):66. 
21. Ikeguchi M, Kouno Y, Kihara K, et al. Evaluation of prognostic markers for patients with curatively resected thoracic esophageal squamous cell carcinomas. Mol Clin Oncol. 2016;5(6):767-772.

22. Geng Y, Shao Y, Zhu D, et al. Systemic immune-inflammation index predicts prognosis of patients with esophageal squamous cell carcinoma: a propensity score-matched analysis. Sci Rep. 2016;6:39482.

23. Xiao Q, Zhang B, Deng X, et al. The preoperative neutrophil-to-lymphocyte ratio is a novel immune parameter for the prognosis of esophageal basaloid squamous cell carcinoma. PLoS One. 2016;11(12):e0168299.

24. Zhu Y, Li M, Bo C, et al. Prognostic significance of the lymphocyte-tomonocyte ratio and the tumor-infiltrating lymphocyte to tumor-associated macrophage ratio in patients with stage T3N0M0 esophageal squamous cell carcinoma. Cancer Immunol Immunother. 2017;66(3):343-354.

25. Huang Y, Feng JF. Low preoperative lymphocyte to monocyte ratio predicts poor cancer-specific survival in patients with esophageal squamous cell carcinoma. Onco Targets Ther. 2015;8:137-145.

26. Han LH, Jia YB, Song QX, Wang JB, Wang NN, Cheng YF. Prognostic significance of preoperative lymphocyte-monocyte ratio in patients with resectable esophageal squamous cell carcinoma. Asian Pac J Cancer Prev. 2015;16(6):2245-2250.

27. Ji WH, Jiang YH, JiYL, Li B, Mao WM. Prechemotherapy neutrophil:lymphocyte ratio is superior to the platelet:lymphocyte ratio as a prognostic indicator for locally advanced esophageal squamous cell cancer treated with neoadjuvant chemotherapy. Dis Esophagus. 2016;29(5):403-411.

28. Jung J, Park SY, Park SJ, Park J. Prognostic value of the neutrophil-tolymphocyte ratio for overall and disease-free survival in patients with surgically treated esophageal squamous cell carcinoma. Tumour Biol. 2016;37(6):7149-7154.

29. Kosumi K, Baba Y, Ishimoto T, et al. Neutrophil/lymphocyte ratio predicts the prognosis in esophageal squamous cell carcinoma patients. Surg Today. 2016;46(4):405-413.

30. Arigami T, Okumura H, Matsumoto M, et al. Analysis of the Fibrinogen and Neutrophil-Lymphocyte Ratio in Esophageal Squamous Cell Carcinoma: A Promising Blood Marker of Tumor Progression and Prognosis. Medicine. 2015;94(42):e1702.

31. Duan H, Zhang X, Wang FX, et al. Prognostic role of neutrophillymphocyte ratio in operable esophageal squamous cell carcinoma. World J Gastroenterol. 2015;21(18):5591-5597.

32. Xie X, Luo KJ, Hu Y, Wang JY, Chen J. Prognostic value of preoperative platelet-lymphocyte and neutrophil-lymphocyte ratio in patients undergoing surgery for esophageal squamous cell cancer. Dis Esophagus. 2016;29(1):79-85.

33. Feng JF, Huang Y, Chen QX. Preoperative platelet lymphocyte ratio (PLR) is superior to neutrophil lymphocyte ratio (NLR) as a predictive factor in patients with esophageal squamous cell carcinoma. World $J$ Surg Oncol. 2014;12:58.
34. Yang Y, Xu H, Zhou L, et al. Platelet to lymphocyte ratio is a predictive marker of prognosis and therapeutic effect of postoperative chemotherapy in non-metastatic esophageal squamous cell carcinoma. Clin Chim Acta. 2018;479:160-165.

35. Sato Y, Gonda K, Harada M, et al. Increased neutrophil-to-lymphocyte ratio is a novel marker for nutrition, inflammation and chemotherapy outcome in patients with locally advanced and metastatic esophageal squamous cell carcinoma. Biomed Rep. 2017;7(1):79-84.

36. Miao C, Zhu S, Pan H, Cao X, Yuan S, Hu X. Combined neutrophilplatelet score and hemoglobin level predict survival in esophageal squamous cell carcinoma patients treated with chemoradiotherapy. Oncotarget. 2017;8(50):87971-87979.

37. Gao GD, Sun B, Wang XB, Wang SM. Neutrophil to lymphocyte ratio as prognostic indicator for patients with esophageal squamous cell cancer. Int J Biol Markers. 2017;32(4):409-414.

38. Kijima T, Arigami T, Uchikado Y, et al. Combined fibrinogen and neutrophil-lymphocyte ratio as a prognostic marker of advanced esophageal squamous cell carcinoma. Cancer Sci. 2017;108(2):193-199.

39. Kunizaki M, Tominaga T, Wakata K, et al. Clinical significance of the C-reactive protein-to-albumin ratio for the prognosis of patients with esophageal squamous cell carcinoma. Mol Clin Oncol. 2018;8(2): 370-374.

40. Yang X, Huang Y, Feng JF, Liu JS. Prognostic significance of neutrophilto- lymphocyte ratio in esophageal cancer: a meta-analysis. Onco Targets Ther. 2015;8:789-794.

41. Yodying H, Matsuda A, Miyashita M, et al. Prognostic Significance of Neutrophil-to-Lymphocyte Ratio and Platelet-to-Lymphocyte Ratio in Oncologic Outcomes of Esophageal Cancer: A Systematic Review and Meta-analysis. Ann Surg Oncol. 2016;23(2):646-654.

42. Huang Y, Sun Y, Peng P, Zhu S, Sun W, Zhang P. Prognostic and clinicopathologic significance of neutrophil-to-lymphocyte ratio in esophageal squamous cell carcinoma: evidence from a meta-analysis. Onco Targets Ther. 2017;10:1165-1172.

43. Zhao QT, Zhang XP, Zhang H, Duan GC. Prognostic role of platelet to lymphocyte ratio in esophageal cancer: A meta-analysis. Oncotarget. 2017;8(67):112085-112093.

44. Gülgün M. Methodology, as well as physiological and pathological conditions, can affect analysis of the lymphocyte-to-monocyte ratio. Rev Port Cardiol. 2017;36(4):323.

45. Wang S, Xiao T, Hu C. Are preoperative platelet-lymphocyte and neutrophil-lymphocyte ratio prognostic factors for patients with esophageal squamous cell cancer? Dis Esophagus. 2016;29(6):704. 


\section{Supplementary material}

Table SI Details of blood testing time, treatment methods, and NOS score of included studies

\begin{tabular}{|c|c|c|c|c|c|}
\hline \multirow[t]{2}{*}{ Study } & \multirow[t]{2}{*}{ Blood exam time } & \multirow[t]{2}{*}{ Treatment } & \multicolumn{3}{|c|}{ Quality assessment with NOS } \\
\hline & & & Selection & Comparability & Outcome \\
\hline Yang et al $(2018)^{\prime}$ & Before surgery & Surgery \pm adj CRT & $* * *$ & $* *$ & $* * *$ \\
\hline Kunizaki et al $(2018)^{2}$ & Before treatment & Surgery/other & $* * *$ & $*$ & $* *$ \\
\hline Sato et al $(2017)^{3}$ & Before treatment & CRT & $* * *$ & $*$ & $* *$ \\
\hline Kijima et al $(2017)^{4}$ & Within 2 weeks before treatment & CRT & $* * *$ & $* *$ & $* *$ \\
\hline Gao et al $(2017)^{5}$ & Before treatment & Surgery \pm adj CRT & $* * *$ & ** & $* *$ \\
\hline Miao et al $(2017)^{6}$ & Before treatment & CRT & $* * *$ & $* *$ & $* *$ \\
\hline Zhou et al $(2017)^{7}$ & Before CRT & CRT & $* * *$ & $* *$ & $* * *$ \\
\hline He et al $(2017)^{8}$ & Within I week before surgery & Surgery \pm adj CRT & $* * * *$ & $* *$ & $* * *$ \\
\hline Liu et al $(2017)^{9}$ & Within I week before CRT & CRT & $* * *$ & $* *$ & $* *$ \\
\hline Zhang et al $(2016)^{10}$ & Before CRT & CRT & $* * *$ & $*$ & $* *$ \\
\hline Zhang et al (2016)" & Within 5 days before surgery & Surgery \pm adj CRT & $* * *$ & $*$ & $* *$ \\
\hline Toyokawa et al $(2016)^{12}$ & Before treatment & $\pm N A C+$ surgery \pm adj CMT & $* * *$ & $*$ & $* * *$ \\
\hline Hirahara et al $(2016)^{13}$ & I week before surgery & Surgery & $* * *$ & $* *$ & $* * *$ \\
\hline Ikeguchi et al $(2016)^{14}$ & Before NAC/surgery & $\pm N A C+$ surgery \pm adj CT & $* * *$ & $*$ & $* *$ \\
\hline Geng et al $(2016)^{15}$ & Before surgery & Surgery & $* * * *$ & $* *$ & $* * *$ \\
\hline Xiao et al $(2016)^{16}$ & Within 2 weeks before CRT & Surgery \pm adj CRT & $* * * *$ & $* *$ & $* * *$ \\
\hline Zhu et al $(2017)^{17}$ & Within 3 days prior to surgery & Surgery \pm adj CRT & $* * *$ & $* *$ & $* * *$ \\
\hline Huang and Feng $(2015)^{18}$ & Within I week before surgery & Surgery \pm adj CRT & $* * *$ & $*$ & $* * *$ \\
\hline Han et al $(2015)^{19}$ & Within I week before surgery & Surgery \pm adj CRT & $* * *$ & $* *$ & $* * *$ \\
\hline Ji et al $(2016)^{20}$ & Before NAC & $\mathrm{NAC}+\mathrm{S}$ & $* * *$ & $*$ & $* * *$ \\
\hline Jung et al $(2016)^{21}$ & Within I week before surgery & Surgery \pm adj CMT & $* * *$ & $*$ & $* *$ \\
\hline Kosumi et al $(2016)^{22}$ & Before NAC/surgery & \pm NAC + surgery \pm adj CMT & $* * *$ & $*$ & $* *$ \\
\hline Arigami et al $(2015)^{23}$ & Within 2 weeks before surgery & Surgery & $* * *$ & $*$ & $* * *$ \\
\hline Duan et al $(2015)^{24}$ & Within I week before surgery & Surgery & $* * *$ & $* *$ & $* * *$ \\
\hline Xie et al $(2016)^{25}$ & Within 10 days before surgery & Surgery \pm adj $C M T$ & $* * *$ & $*$ & $* *$ \\
\hline Feng et al $(2014)^{26}$ & Within I week before surgery & Surgery & $* * *$ & $* *$ & $* * *$ \\
\hline
\end{tabular}

Abbreviations: NOS, Newcastle-Ottawa scale; CRT, chemoradiotherapy; CT, computed tomography; adj, adjuvant; S, surgery; NAC, neoadjuvant chemotherapy; CMT, chemoradiotherapy.

\section{References}

1. Yang $\mathrm{Y}, \mathrm{Xu} \mathrm{H}, \mathrm{Zhou} \mathrm{L}$, et al. Platelet to lymphocyte ratio is a predictive marker of prognosis and therapeutic effect of postoperative chemotherapy in non-metastatic esophageal squamous cell carcinoma. Clin Chim Acta. 2018;479:160-165.

2. Kunizaki M, Tominaga $\mathrm{T}$, Wakata $\mathrm{K}$, et al. Clinical significance of the C-reactive protein-to-albumin ratio for the prognosis of patients with esophageal squamous cell carcinoma. Mol Clin Oncol. 2018;8(2):370-374.

3. Sato Y, Gonda K, Harada M, et al. Increased neutrophil-to-lymphocyte ratio is a novel marker for nutrition, inflammation and chemotherapy outcome in patients with locally advanced and metastatic esophageal squamous cell carcinoma. Biomed Rep. 2017;7(1):79-84.

4. Kijima T, Arigami T, Uchikado Y, et al. Combined fibrinogen and neutrophil-lymphocyte ratio as a prognostic marker of advanced esophageal squamous cell carcinoma. Cancer Sci. 2017;108(2):193-199.

5. Gao GD, Sun B, Wang XB, Wang SM. Neutrophil to lymphocyte ratio as prognostic indicator for patients with esophageal squamous cell cancer. Int J Biol Markers. 2017;32(4):409-414.

6. Miao C, Zhu S, Pan H, Cao X, Yuan S, Hu X. Combined neutrophilplatelet score and hemoglobin level predict survival in esophageal squamous cell carcinoma patients treated with chemoradiotherapy. Oncotarget. 2017;8(50):87971-87979.

7. Zhou XL, Li YQ, Zhu WG, et al. Neutrophil-to-lymphocyte ratio as a prognostic biomarker for patients with locally advanced esophageal squamous cell carcinoma treated with definitive chemoradiotherapy. Sci Rep. 2017;7:42581.
8. He YF, Luo HQ, Wang W. Preoperative NLR and PLR in the middle or lower ESCC patients with radical operation. Eur J Cancer Care. 2017;26(2).

9. Liu X, Li M, Zhao F, et al. The lymphocyte-monocyte ratio predicts tumor response and survival in patients with locally advanced esophageal cancer who received definitive chemoradiotherapy. Onco Targets Ther. 2017;10:871-877.

10. Zhang P, Xi M, Zhao L, et al. Comparison of two inflammation-based prognostic scores in patients with thoracic esophageal cancer undergoing chemoradiotherapy. Int J Clin Exp Med. 2016;9(2):1764-1771.

11. Zhang F, Chen Z, Wang P, Hu X, Gao Y, He J. Combination of platelet count and mean platelet volume (COP-MPV) predicts postoperative prognosis in both resectable early and advanced stage esophageal squamous cell cancer patients. Tumour Biol. 2016;37(7): 9323-9331.

12. Toyokawa T, Kubo N, Tamura T, et al. The pretreatment Controlling Nutritional Status (CONUT) score is an independent prognostic factor in patients with resectable thoracic esophageal squamous cell carcinoma: results from a retrospective study. BMC Cancer. 2016;16:722.

13. Hirahara N, Matsubara T, Mizota Y, Ishibashi S, Tajima Y. Prognostic value of preoperative inflammatory response biomarkers in patients with esophageal cancer who undergo a curative thoracoscopic esophagectomy. BMC Surg. 2016;16(1):66.

14. Ikeguchi M, Kouno Y, Kihara K, et al. Evaluation of prognostic markers for patients with curatively resected thoracic esophageal squamous cell carcinomas. Mol Clin Oncol. 2016;5(6):767-772. 
15. Geng Y, Shao Y, Zhu D, et al. Systemic immune-inflammation index predicts prognosis of patients with esophageal squamous cell carcinoma: a propensity score-matched analysis. Sci Rep. 2016;6:39482.

16. Xiao Q, Zhang B, Deng X, et al. The preoperative neutrophil-to-lymphocyte ratio is a novel immune parameter for the prognosis of esophageal basaloid squamous cell carcinoma. PLoS One. 2016;11(12):e0168299.

17. Zhu Y, Li M, Bo C, et al. Prognostic significance of the lymphocyte-to-monocyte ratio and the tumor-infiltrating lymphocyte to tumor-associated macrophage ratio in patients with stage T3N0M0 esophageal squamous cell carcinoma. Cancer Immunol Immunother. 2017;66(3):343-354.

18. Huang Y, Feng JF. Low preoperative lymphocyte to monocyte ratio predicts poor cancer-specific survival in patients with esophageal squamous cell carcinoma. Onco Targets Ther. 2015;8:137-145.

19. Han LH, Jia YB, Song QX, Wang JB, Wang NN, Cheng YF. Prognostic significance of preoperative lymphocyte-monocyte ratio in patients with resectable esophageal squamous cell carcinoma. Asian Pac J Cancer Prev. 2015;16(6):2245-2250.

20. Ji WH, Jiang YH, Ji YL, Li B, Mao WM. Prechemotherapy neutrophil: lymphocyte ratio is superior to the platelet:lymphocyte ratio as a prognostic indicator for locally advanced esophageal squamous cell cancer treated with neoadjuvant chemotherapy. Dis Esophagus. 2016;29(5):403-411.
21. Jung J, Park SY, Park SJ, Park J. Prognostic value of the neutrophil-tolymphocyte ratio for overall and disease-free survival in patients with surgically treated esophageal squamous cell carcinoma. Tumour Biol. 2016;37(6):7149-7154.

22. Kosumi K, Baba Y, Ishimoto T, et al. Neutrophil/lymphocyte ratio predicts the prognosis in esophageal squamous cell carcinoma patients. Surg Today. 2016;46(4):405-413.

23. Arigami T, Okumura H, Matsumoto M, et al. Analysis of the Fibrinogen and Neutrophil-Lymphocyte Ratio in Esophageal Squamous Cell Carcinoma: A Promising Blood Marker of Tumor Progression and Prognosis. Medicine. 2015;94(42):e1702.

24. Duan H, Zhang X, Wang FX, et al. Prognostic role of neutrophillymphocyte ratio in operable esophageal squamous cell carcinoma. World J Gastroenterol. 2015;21(18):5591-5597.

25. Xie X, Luo KJ, Hu Y, Wang JY, Chen J. Prognostic value of preoperative platelet-lymphocyte and neutrophil-lymphocyte ratio in patients undergoing surgery for esophageal squamous cell cancer. Dis Esophagus. 2016;29(1):79-85.

26. Feng JF, Huang Y, Chen QX. Preoperative platelet lymphocyte ratio (PLR) is superior to neutrophil lymphocyte ratio (NLR) as a predictive factor in patients with esophageal squamous cell carcinoma. World $J$ Surg Oncol. 2014;12:58.
Cancer Management and Research

\section{Publish your work in this journal}

Cancer Management and Research is an international, peer-reviewed open access journal focusing on cancer research and the optimal use of preventative and integrated treatment interventions to achieve improved outcomes, enhanced survival and quality of life for the cancer patient. The manuscript management system is completely online and includes

\section{Dovepress}

a very quick and fair peer-review system, which is all easy to use. Visit http://www.dovepress.com/testimonials.php to read real quotes from published authors. 